\title{
Perceptions of the Quality of Nature-Based Tourism in Sundarban in Local and Foreign Visitors: A Case Study from Karamjal, Mongla
}

\author{
A. H. M. R. Sarker ${ }^{1}$, Eivin Røskaft ${ }^{2}$, Ma-Suza ${ }^{1}$, M. M. Abdullah Al-Mamun ${ }^{1}, \&$ Mohammad Nur Nobi $^{3}$ \\ ${ }^{1}$ Institute of Forestry and Environmental Sciences, University of Chittagong, Chittagong 4331, Bangladesh \\ ${ }^{2}$ Department of Biology, Norwegian University of Science and Technology (NTNU), Realfagbygget, Norway \\ ${ }^{3}$ Department of Economics, University of Chittagong, Chittagong 4331, Bangladesh \\ Correspondence: Eivin Røskaft, Department of Biology, Norwegian University of Science and Technology \\ (NTNU), Realfagbygget, Norway. Email: eivin.roskaft@ntnu.no
}

Received: November 28, 2016

Accepted: December 28, 2016

Online Published: January 9, 2017

doi:10.5539/enrr.v7n1p1

URL: http://dx.doi.org/10.5539/enrr.v7n1p1

\begin{abstract}
The recreational behaviour of visitors to Karamjal Forest Station in Sundarban, Bangladesh, was determined by interviewing 150 visitors. The majority of visitors were locals from Bangladesh (90\%); however, recreational behaviour varied significantly between local and foreign visitors. More than half of the visitors reported coming to Sundarban for the first time. Most of the visitors were travelling for recreation and derived satisfaction from watching wildlife, particularly deer and crocodiles, and the beauty of the forest. Foreign visitors expressed more satisfaction with boat journeys than local visitors, while less educated visitors expressed more dissatisfaction with boat travel than highly educated visitors. To the question, 'How would you describe the quality of the recreational benefits of nature-based tourism in Karamjal?' most visitors answered "poor" or "very poor". Visitor perception varied significantly by income level, and people of higher financial status were more satisfied than people of lower financial status with the recreational benefits of nature-based tourism in Karamjal.
\end{abstract}

Keywords: recreational behaviour, visitors, Karamjal, Sundarban, financial status

\section{Introduction}

Tourism is among the most rapidly growing industries worldwide. According to the World Tourism Organization, international tourism is growing at a rate of approximately 4\% per year WTO (2000). Growing environmental concern coupled with emerging dissatisfaction with mass tourism has led to an increased demand for nature-based tourism. Nature-based tourism offers third world countries with a means of earning foreign currency through a less destructive use of natural resources (Honey, 2008). Protected areas (PAs) are important components of the naturebased tourism industry (Mallya, 2006). PAs generally occupy some of the most interesting landscapes within a country. Today, nature-based tourism has become increasingly important for sustainable development because of its potential to contribute to local and national economic development while also providing incentives for nature and biodiversity conservation. Over the past two decades, tourism has grown rapidly in Bangladesh, and tourism has become an important and dynamic industry within the country (Hasan, 2012). However, even after 40 years of independence, the country has not yet reached a similar position in the tourism sector to neighbouring countries, such as India and Nepal (Hai \& Chik, 2011). Although Bangladesh has the capacity for potential growth, tourism has been growing at a very slow pace compared to neighbouring countries. The GDP contribution from tourism remains at less than $1 \%$ (BBS, 2011). Thus, it is clear that there are discrepancies in the degree of initiative to attract visitors in Bangladesh.

The Sundarban - the world's largest single patch mangrove - is a famous World Heritage site. It is located on the southern coast of Bangladesh and comprises a unique habitat for approximately 300 species of flora, 425 species of terrestrial fauna and 291 species of fish, some of which are threatened and endangered (Biswas, Choudhury, Nishat, \& Rahman, 2007). Tourism was first allowed inside the Sundarban in 1987 by Office Order Number 66, dated January 1, 1987; however, Guide Tours - a private tour operator - has been reported to have begun organizing trips to Sundarban in 1981 (personal communication with Mr. Hasan Mansur, Chairman, the Guide Tour). In 1995, a 10-year development plan for the implementation of nature-based tourism activities in the Sundarban was presented as a part of the Food and Agricultural Organization's (FAO) integrated resource 
development plan for the Sundarban Forest Reserve. It was, however, never implemented. From 1998 to 2003, the Sundarban Biodiversity Conservation project developed an integrated conservation and development plan including infrastructure to support sustainable production, promote ecotourism and enhance conservation. Different tourist facilities, such as an observation tower, wooded boardwalk trail, and rest area, were constructed. Initially, tourists only visited the Kotka-Kochikhali area during 3 to 4 day board motor launches. Later on, in 2003, the Forest Department developed a tourist attraction in Karamjal. Another spot was established in Harbaria in 2005 for day-long excursions. Karamjal is one of the entry points of the Sundarban Forest Reserve and the closest entry point to the Mongla Port. The only legal way to travel independently into the Sundarban Forest Reserve from Mongla is on a day trip to the Karamjal Forest Station.

Sundarban has the potential to attract a large number of visitors and be a source of earning through national and international tourism opportunities that may ultimately improve the livelihood of surrounding human populations (Das \& Bandyopadhyay, 2013; Iqball et al., 2010). In the Indian part of Sundarban, a study revealed that only a small number of local people were involved in tourism. Although their jobs were seasonal in nature, they were found to be economically better-off than other individuals from the same area (Guha \& Ghosh, 2007). The Bangladesh government has expressed interest in expanding potential opportunities associated with the Sundarban. It is important to note that it is possible for mangrove conservation to be compatible with tourism if well-planned. Well-planned tourism has the potential to provide economic and political incentives for proper management and conservation and bring additional benefits to local communities and regional economies (Haque \& Aich, 2014). However, the success of a management regime can contribute to promoting the success of these strategies. Measuring the success of any management regime can be performed by assessing its impact on the perceptions of satisfaction and enjoyment in tourists visiting an attraction (Wightm, 1996). A good management regime may be highly associated with visitor satisfaction. No research has been carried out to explore visitor satisfaction and enjoyment during travel to Sundarban. We hypothesized that there would be no variation in recreational behaviours between local and foreign visitors. We also hypothesized that social characteristics would influence the visitors' perceptions of the quality of the recreational benefits of nature-based tourism in Karamjal, Sundarban. In the light of aforementioned assumptions, the objectives of this study were as follows: (i) to identify the socioeconomic status of visitors, (ii) to explore the recreational behaviour of visitors, and (iii) to determine visitor perceptions of the quality of the recreational benefits of nature-based tourism in Karamjal, Sundarban, Bangladesh. The present study acknowledges the fact that identifying tourist perceptions may produce useful information for the monitoring system for tourism quality. Thus, the results of this study may be used to build scenarios and simulation models and integrated into an optimal approach to tourism planning (Folke et al., 2002; Walker et al., 2002). The visitors' perceptions of recreational benefits can also provide a good basis for the planning and management of naturebased tourism in Sundarban.

\section{Materials and Methods}

\subsection{Site Description}

The Sundarban Forest Reserve is situated in the southwestern region (Khulna division) of Bangladesh along the coastline of the Bay of Bengal. It is the world's largest mangrove forest, declared as a World Heritage Site by UNESCO in 1997 under criteria IX and X. The total area of the forest is $601,700 \mathrm{ha}$, and the reserve consists of three wildlife sanctuaries: West Sundarban (71,303 ha), East Sundarban (31,227 ha) and South Sundarban (36,970 ha). All these sanctuaries were designated as protected areas by IUCN in 1996 under criteria IV (Siddiqi, 2001). The four forest ranges in Sundarban are managed by the Bangladesh Forest Department. According to the IUCN Red Data Book, 28 endangered species of animals and plants are found in Sundarban (IUCN, 2015).

The Sundarban Forest Reserve has a unique ecosystem, exceptional scenic beauty and rich wildlife that can be a source of attraction for a variety of people and provide a convenient space for outdoor recreation. The site is representative of a substantial number of ongoing ecological and biological processes in the evolution and development of mangrove ecosystems and plant and animal communities. Ecotourism can be developed without causing damage to vegetation or wildlife. Adequate water transportation and tourist accommodation facilities inside the forests can attract more domestic and foreign visitors.

The unique natural beauty of Sundarban attracts both local and foreign tourists. The most attractive tourist spots in Sundarban include Karamjal, Harbaria, Supati, Katka, Kochikhali, Neelkamal, Dublarchar, the Shekhertek Temple, the Mandarbaria beach, Dobeki, Kalirchar, and Mrigamari. Of these attractions, Karamjal has been most visited by tourists (Figure 1). Karamjal is an ideal location for daylong visits to Sundarban. Small capacity boats may be chartered from Mongla to visit Karamjal. No prior permission from the Forest Department is required to visit Karamjal. However, the entry fee is Tk. 10 (US\$ 0.10) per person. An arboretum of the Sundarban Forest 
Reserve is in Karamjal. In the arboretum, visitors can walk along a wooden foot trail, and the arboretum is a miniaturized replica of Sundarban. Almost all tree species found in the Sundarban Forest Reserve have been planted in the arboretum under natural conditions. The crocodile breeding centre, deer, and monkey rehabilitation centre are special attractions in Karamjal.

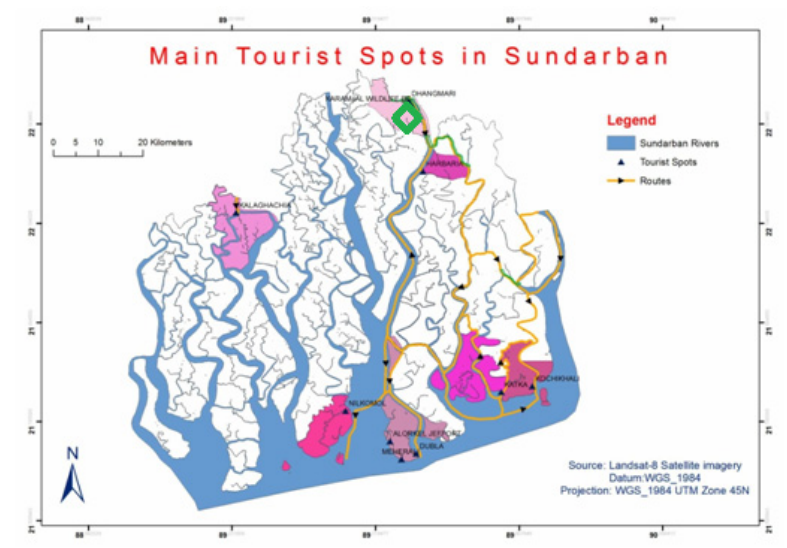

Figure 1. Map of the sampling site

\subsection{Data Collection and Data Analysis}

Prior to this study's fieldwork, secondary resources, including published and unpublished research studies, were identified and analysed to obtain information regarding the nature-based tourism practices in Sundarban. In total, 150 visitors were randomly selected and interviewed using a semi-structured questionnaire at Karamjal Forest Station, Mongla. The questionnaire included questions related to the socioeconomic and demographic characteristics of the visitor (e.g., gender, age, literacy rate, marital status, occupation, household size and financial status). Furthermore, the questionnaire included questions related to the visitor's recreational behaviour (e.g., frequency of visits, use of a tour package, whether they travelled alone, sources of information about tourism in Sundarban, purpose of visit, duration of the trip and the financial source used to cover the expenses of the trip). The visitor's attitudes towards recreational nature-based tourism activities in Sundarban (e.g., satisfaction level with tourism activities in visitors) and towards the quality of the recreational benefits of nature-based tourism in Sundarban (i.e., very poor, poor, good and very good) were also recorded. Tourist visits to the Sundarban mainly occurred during the winter months (i.e., November to February). Therefore, fieldwork was carried out during these months in 2014 and 2015.

After collection, primary raw data were sorted on the basis of importance and usability for the purpose of performing an easy, meaningful and high quality quantitative analyses. After coding and digitalizing collected data, data analyses were performed using SPSS version 20.0 (SPSS, Chicago, USA). Differences in socioeconomic status and recreational behaviour in visitors were explored using one-way ANOVA and chi-square $\left(\chi^{2}\right)$ tests. The latter tests were used because of the non-linearity of the data; however, stepwise binary logistic and linear regression analyses were performed to examine variations in the visitors' socio-demographic characteristics and satisfaction level with the recreational events in Sundarban [i.e., (1) "Are you satisfied with watching the wildlife and beauty of the forest?" (yes or no), (2) "Did you enjoy the boat journey to Sundarban?" (yes or no), and (3) "What is your perception of the quality of the recreational benefits of nature-based tourism in Sundarban?" (i.e., very poor, poor, good or very good)]. We included the type of visitor (local or foreigner) as the independent variables in the predictive models and different sociodemographic variables [i.e., gender (male or female); age: i.e., young (18 to 30 years), middle-aged (31 to 50 years) or old (above 50 years); literacy level: i.e., less educated (below or equivalent to higher secondary certificate) or highly educated (above higher secondary certificate); employment status: i.e., employed as service providers or in the technical professions, government/NGO service, or business or unemployed; household size: i.e., small (up to 5 persons) or large (above 5 persons); and financial/income status: i.e., low (monthly income up to Tk. 12,000), medium (monthly income Tk. 12,001 to 30,000 ) or high (monthly income above Tk. 30,000)] as dependent variables. The level of significance was set at $\mathrm{p} \leq 0.05$. 


\section{Results}

\subsection{Socio-Demographic Analyses}

The majority of visitors were locals from Bangladesh $(90.7 \% ; n=150)$, while the remaining tourists $(9.7 \%)$ were visiting from the USA, Germany, Luxemburg, Sri Lanka, Nepal, and India. In further analyses, we therefore use two groups: local and foreigner visitors. Among the local visitors $(n=136)$, the highest proportion were from the Khulna division (52.9\%), while the remaining local visitors were from the Dhaka (26.5\%), Chittagong (8.8\%), Rajshahi (6.6\%), Barisal (2.9\%), Rangpur (1.5\%) and Sylhet $(0.7 \%)$ divisions. Visitors was employed in government or non-government services $(34 \%)$, business $(34 \%)$, and technical professions $(20 \%)$ or were unemployed $(9.3 \%)$ or service providers $(2.7 \%)$; occupations differed significantly between the two groups of visitors $\left(\chi^{2}=10.60, \mathrm{df}=4, p=0.032\right)$. The highest proportion of local visitors were involved in business $(36 \%)$, followed by government/NGO services (33.8\%), and technical professions (16.9\%); additionally, some visitors were unemployed $(10.3 \%)$ or service providers $(2.9 \%)$. Among the foreigners, $50 \%$ of the visitors were involved in technical professions, while the remaining was involved in government and NGO services $(35.7 \%)$ or business professionals (14.3\%). The average household size among the visitors was 4.3 persons. The household size also differed significantly between the two types of visitors (i.e., local visitor: $5.1 \pm 4.4$ persons per household, foreign visitor: $3.0 \pm 1.5$ persons per household, $\mathrm{F}=3.097 \mathrm{df}=1, p=0.050$ ). Of the visitors, $50 \%$ had higher income status and more than $40 \%$ belonged to the medium income status. The average monthly income of visitors was Tk. $72,123 \pm 10,393$. However, the average monthly income of visitors differed significantly between the two types of visitors (i.e., local visitors: Tk. 52,548 $\pm 8,079$ per month, foreign visitors: Tk. 262,286 $\pm 114,478$ per month, $\mathrm{F}=78.60, \mathrm{df}=1, p<0.0001)$. Among visitors, the proportion of males $(90 \%)$ was significantly higher than females; the gender distribution was significantly different between local $(91.9 \%)$ and foreign visitors $\left(71.4 \%, \chi^{2}\right.$ $=5.92, \mathrm{df}=1, p=0.015)$. The average age of visitors was $37.1 \pm 11.9(\mathrm{SD})$ years. The highest proportion of visitors belonged to the middle age group (46.7\%) compared to the young (40\%) and old $(13.3 \%)$ age groups. Among local visitors, the majority of visitors belonged to middle age group (48.5\%) compared to the young $(36.8 \%)$ and old $(14.7 \%)$ age groups, while among foreigners, the highest proportion of visitors were in the young age group (71.4\%) and middle aged group (28.6\%), and none of the foreign visitors were in the old group (0\%) $\left(\chi^{2}=6.96, \mathrm{df}=2, p=0.031\right)$. More than half of the visitors were highly educated $(56.7 \%)$, and the proportion of highly educated visitors was significantly higher among foreign tourists $(92.9 \%)$ than local tourists $\left(52.9 \%, \chi^{2}=\right.$ $8.24, \mathrm{df}=1, p=0.004)$.

A binary logistic regression analysis was performed to examine socio-demographic conditions significantly associated with visitor type, using the two categories of visitors (i.e., local or foreign) as a dependent variable and sociodemographic characteristics as four independent variables including gender (i.e., male or female), education (i.e., less educated or highly educated), age (i.e., young or old) and household size (i.e., small or large). Only three of these variables were significantly associated with visitor type (Table 1).

Table 1. Results of logistic regression analyses examining the effects of 4 independent sociodemographic variables on visitor type

\begin{tabular}{lllllll}
\hline Independent variables & $\mathrm{B}$ & S.E. & $\chi^{2}$ & df & $p$ & Odds ratio $^{1}$ \\
\hline Gender & 1.667 & 0.719 & 5.373 & 1 & 0.020 & 5.295 \\
Age & -1.584 & 0.812 & 3.806 & 1 & 0.051 & 0.205 \\
Education & 2.087 & 1.079 & 3.738 & 1 & 0.053 & 8.061 \\
Household size & -18.333 & 9390.79 & 0.000 & 1 & 0.998 & 0.000
\end{tabular}

1 A measure of association between the dependent variable and independent variable. When $\mathrm{B}$ was negative, the odds ratio was inverted (1/odds ratio) to indicate the relevant odds.

${ }^{2}$ Cox \& Snell $\mathrm{R}^{2} 0.143$, Nagelkerke $\mathrm{R}^{2} 0.310$.

The analysis revealed that of the socio-demographic variables, gender was most significantly associated with visitor type. The odds of being a female visitor were 5.29 times greater in foreign than local visitors. Age was the socio-demographic variables with the second highest association with visitor type. The odds that a visitor was in the young age group were 4.9 times higher in foreign than local visitors. Education level was the sociodemographic variable that was third most highly associated with the type of visitor. The odds that a visitor was highly educated were 8 times greater in foreign than local visitors. However, household size did not differ significantly by type of visitor. 


\subsubsection{Recreational Behaviour in Visitors}

When asked, "Is this your first time to visit Sundarban?" more than half of the visitors said, "Yes," $(n=150$, $56.7 \%)$ and the response to the aforementioned question differed significantly between the two types of visitors (local visitors: $84.7 \%$, foreign visitors: $15.3 \%, \chi^{2}=8.24, \mathrm{df}=1, p=0.004$ ). Among visitors, the proportion of locals who reported having visited Karamjal repeatedly (98.5\%) was significantly higher than the proportion of foreigners reporting repeated visits $\left(1.5 \%, \chi^{2}=8.24, \mathrm{df}=1, p=0.004\right)$. More than $3 / 4$ of the visitors $(76 \%)$ reported that they came to Karamjal, Sundarban as part of a trip package that included other tourist locations in Sundarban when asked, 'Have you come under a package trip?' This proportion was considerably higher among local visitors $(93.9 \%)$ than among foreign visitors $\left(6.1 \%, \chi^{2}=5.72, \mathrm{df}=1, p=0.017\right)$. The average cost of the package was Tk. $26,503 \pm 5,215$. The mean cost per trip varied significantly by tourist type (i.e., local visitors: Tk. $14,099 \pm 2,037$, foreign visitors: Tk. $147,000 \pm 9,803, \mathrm{~F}=183.4, \mathrm{df}=1, p<0.0001)$. Very few visitors $(18 \%)$ travelled alone, and the proportion travelling alone differed significantly between local (15.4\%) and foreign visitors $\left(42.9 \%, \chi^{2}=6.46, \mathrm{df}=1, p=0.011\right)$. Visitors were more likely to travel in a group (48.8\%) than with family $(35.8 \%)$ or friends $(15.4 \%)$, and travelling companions varied significantly between the two types of visitors $\left(\chi^{2}=6.08, \mathrm{df}=2, p=0.048\right)$. Approximately $38.3 \%$ of local visitors visited Sundarban with family, while no foreign visitors visited with family. The majority of local visitors came to the Sundarban Forest Reserve as part of a group (47.8\%) or with friends (13.9\%), while among foreigners, $62.5 \%$ visited with a group, and the remaining $37.5 \%$ visited with friends. When asked, 'Where did you obtain information about tourism in Sundarban?' most of the visitors $(61.5 \%)$ reported "friends and relatives", followed by the media $(23.1 \%)$, tour operator advertisement (1.5\%), governmental agencies (3.1\%), websites (1.5\%) and social networks $(9.3 \%)$. Responses varied significantly between the two types of visitors $\left(\chi^{2}=34.61, \mathrm{df}=1, p<0.0001\right)$. Approximately $28.6 \%$ of foreign visitors reported a "governmental agency" as one of the sources of information, while no local visitors reported receiving information from the government. More than 3/4 of the respondents reported that they visited Sundarban mostly for recreation (76\%), while the remaining reported that the purposes of their visit were research $(12.7 \%)$, business $(2 \%)$, and spiritual $(9.3 \%)$. The purpose of the visit differed significantly between the two types of visitors $\left(\chi^{2}=20.11, \mathrm{df}=1, p<0.0001\right)$. Almost $50 \%$ of foreign visitors reported "research" as a purpose of their visit, while among local visitors, the proportion reporting this purpose was only $8.8 \%$.

More than $86 \%$ of visitors visited Sundarban for a short duration ( 3 to 7 days), while the remaining (13\%) reported visiting for more than one week. More than $3 / 4$ of the visitors covered the expenditure of the trip using their own income $(77.1 \%)$, while the remaining reported that travel expenses were covered by family income $(10.1 \%)$ and organizational sponsorship (12.8\%). This response varied significantly between the two types of visitors $\left(\chi^{2}=\right.$ $13.34, \mathrm{df}=1, p=0.001)$. Most foreign visitors (42.9\%) reported that they received financial support from an organization, while among local visitors, the rate of organization support was only $9.6 \%$. Moreover, no foreign visitors mentioned "family" as a source of funding for their travel expenses.

A binary logistic regression analysis was performed to examine recreational behaviour variables associated with visitor type, using the type of visitor (i.e., local and foreign) as the dependent variable and five independent variables, including "Was this your first time of visiting Sundarban?" (yes or no), "Are you travelling alone?" (yes or no), "Is your visit part of a trip package?" (yes or no), "Is Sundarban your only destination of visiting this region?" (yes or no) and "How are you covering the expenses of your trip?" (own funding or support from others such as family or an organization). Only four of these variables were significantly associated with visitor type (Table 2). The analysis revealed that the recreational behaviour variable most highly associated with the type of visitor was whether the trip was part of a package. The odds of travelling to Sundarban as part of a package were 6.49 times greater in local than foreign visitors. Among the recreational behaviour variables, visiting Sundarban repeatedly was the second most highly associated with the type of visitor. The odds of visiting repeatedly were 12.4 times higher in local than foreign visitors. The third important predictor of visitor type was visiting only Sundarban. The odds of only visiting Sundarban were 5.1 times greater in local than foreign visitors. The fourth important predictor was whether the visitor travelled alone or not. The odds of travelling alone were 4.2 times greater in foreign than local visitors. However, among the recreational behaviour variables, the source of the money used to cover travel costs did not differ significantly by type of visitor.

\subsubsection{Satisfaction Level of Different Recreational Events of Nature-based Tourism in Karamjal, Sundarban}

Among visitors, the satisfaction level with tourism activities varied significantly between the two groups of visitors (Table 3). Nearly about half of visitors expressed satisfaction with watching wildlife and the beauty of the forest and more than half of visitors expressed dissatisfaction with the boat journey. A stepwise linear regression was performed to examine variation in visitor perceptions, using the response to the question, "Are you satisfied with watching wildlife and the beauty of the forest?" as the dependent variable and including seven independent 
variables (Table 4). However, only one variable (i.e., type of visitors: local or foreigner) was found to be a significant contributor to the variation in this perception. Foreign visitors expressed more satisfaction than did local visitors. The independent variables explained only 3.2\% of the variation in visitor attitudes regarding their satisfaction level with watching wildlife and the beauty of forest in Sundarban.

We performed another stepwise linear regression to examine variation in visitor perceptions, using the response to the question, "Did you enjoy the boat journey to Sundarban?" as a dependent variable and including seven independent variables (Table 4). However, only two variables (i.e., type of visitor and literacy level) were found to be significant contributors to the variation in this perception. Foreign visitors expressed more satisfaction compared to local visitors, and less educated visitors expressed more dissatisfaction with the boat journey than did highly educated visitors. The independent variables explained $10.5 \%$ of the variation in the attitudes relating to visitor satisfaction level with the boat journey in the Sundarban Forest Reserve.

Table 2. Results of logistic regression analyses examining the effects of 5 independent recreational behaviour variables on visitor type

\begin{tabular}{lllllll}
\hline Independent variables & B & S.E. & $\chi^{2}$ & df & $p$ & Odds ratio $^{1}$ \\
\hline Trip with or without package & -1.873 & 0.792 & 5.599 & 1 & 0.018 & 0.154 \\
First time visitor (yes/no) & 2.519 & 1.107 & 5.181 & 1 & 0.023 & 12.420 \\
Only visit to Sundarban & -1.625 & 0.761 & 4.556 & 1 & 0.033 & 0.197 \\
Travelled alone (yes/no) & 1.442 & 0.691 & 4.360 & 1 & 0.037 & 4.229 \\
Source of money to cover travel cost & 0.037 & 0.555 & 0.005 & 1 & 0.946 & 1.038 \\
\hline
\end{tabular}

${ }_{1}^{1}$ Measure of association between the dependent variable and independent variable. When B was negative, the odds ratio was inverted (1/odds ratio) to indicate the relevant odds.

${ }^{2}$ Cox \& Snell $\mathrm{R}^{2} 0.164$, Nagelkerke $\mathrm{R}^{2} 0.353$.

Table 3. Visitor satisfaction with recreational nature-based tourism activities in Karamjal, Sundarban and $\chi^{2}$ tests of independence by type of visitor

\begin{tabular}{|c|c|c|c|c|c|c|c|}
\hline \multirow{2}{*}{$\begin{array}{l}\text { Visitors' satisfaction towards recreational } \\
\text { activities of nature based tourism in Sundarban }\end{array}$} & \multicolumn{3}{|c|}{ Type of visitor } & \multirow{2}{*}{$\begin{array}{c}\text { Total } \\
(n=150)\end{array}$} & \multicolumn{3}{|c|}{ Statistics } \\
\hline & & Local $(n=136)$ & Foreign $(n=14)$ & & $\chi^{2}$ & $\mathrm{df}$ & $p$ \\
\hline \multirow[t]{2}{*}{ Watching wildlife and beauty of forest } & no & $52.2 \%$ & $21.4 \%$ & $50.7 \%$ & & & \\
\hline & yes & $47.8 \%$ & $78.6 \%$ & $49.3 \%$ & 4.81 & 1 & 0.028 \\
\hline \multirow[t]{2}{*}{ Enjoying boat journey } & no & $55.1 \%$ & $21.4 \%$ & $52.0 \%$ & & & \\
\hline & yes & $44.9 \%$ & $78.6 \%$ & $48.0 \%$ & 5.78 & 1 & 0.016 \\
\hline
\end{tabular}

Table 4. Stepwise linear regression analysis of visitors' satisfaction level with recreational events in Karamjal, Sundarban (dependent variables) in association with various independent variables. $\mathrm{R}^{2}$ value explaining the variation in visitors' perceptions

\begin{tabular}{|c|c|c|c|c|}
\hline \multirow[t]{3}{*}{ Independent variables } & \multicolumn{4}{|c|}{ Dependent variables } \\
\hline & \multicolumn{2}{|c|}{$\begin{array}{l}\text { Are you satisfied with watching the } \\
\text { wildlife and beauty of the forest? }\end{array}$} & \multicolumn{2}{|c|}{$\begin{array}{l}\text { Did you enjoy the boat journey } \\
\text { to the forest? }\end{array}$} \\
\hline & $\mathrm{t}$ & $p$ & $\mathrm{t}$ & $p$ \\
\hline Type of visitor & 2.210 & 0.028 & 3.361 & 0.001 \\
\hline Literacy level & -1.520 & 0.131 & -3.292 & 0.001 \\
\hline Household size & 1.420 & 0.158 & 1.673 & 0.096 \\
\hline Occupation & -1.401 & 0.163 & -0.651 & 0.516 \\
\hline Gender & -1.350 & 0.179 & 1.030 & 0.305 \\
\hline Age of visitor & 0.222 & 0.825 & -0.328 & 0.744 \\
\hline Monthly income (Tk.) & 0.141 & 0.888 & 0.176 & 0.860 \\
\hline Constant & 1.082 & 0.021 & 2.205 & 0.029 \\
\hline $\mathrm{R}^{2}$ & 0.032 & & 0.105 & \\
\hline
\end{tabular}




\subsubsection{Quality of the Recreational Benefits of Nature-based Tourism in Karamjal, Sundarban}

When asked, 'How would you describe the quality of recreational benefits of nature-based tourism in Karamjal, Sundarban?' a high proportion of visitors reported "poor," and a considerable proportion reported "very poor". Only a few visitors reported "very good" or "good." The response to this question varied significantly between the two types of visitors (Table 5). Among the foreign visitors, a higher proportion described the quality of the recreational benefits in Karamjal, Sundarban as "very good", while the majority of the local visitors described the quality as "poor" or "very poor".

Table 5. Frequency analysis of the perception of the quality of the recreational benefits of nature-based tourism in Karamjal, Sundarban among visitors and $\chi^{2}$ tests of independence by type of visitor.

\begin{tabular}{|c|c|c|c|c|c|c|}
\hline \multirow{2}{*}{ Quality of recreational benefits } & \multicolumn{2}{|c|}{ Type of visitor } & \multirow{2}{*}{ Total $(n=150)$} & \multicolumn{3}{|c|}{ Statistics } \\
\hline & Local $(n=136)$ & Foreigner $(n=14)$ & & $\chi^{2}$ & $\mathrm{df}$ & $p$ \\
\hline Very poor & $38.2 \%$ & $28.6 \%$ & $37.3 \%$ & & & \\
\hline Poor & $42.6 \%$ & $14.3 \%$ & $40.0 \%$ & & & \\
\hline Good & $8.1 \%$ & $14.3 \%$ & $8.7 \%$ & & & \\
\hline Very good & $11.0 \%$ & $42.9 \%$ & $14.0 \%$ & 12.62 & 3 & 0.006 \\
\hline
\end{tabular}

A stepwise linear regression was performed to examine the variation in visitor perceptions using the response to the question, "How would you describe the quality of the recreational benefits of nature-based tourism in Karamjal, Sundarban?" as the dependent variable and including seven independent variables (Table 6). However, only one variable (i.e., financial status) was found to be a significant contributor to the variation in this perception. Visitors of higher financial status expressed more positive attitudes towards the quality of the recreational benefits of nature-based tourism in Karamjal, Sundarban than did visitors of lower financial status. The independent variables explained $5.5 \%$ of the variation in visitor attitudes relating to the recreational benefits of the Karamjal Forest Station in Sundarban.

Table 6. Results of a stepwise linear regression analysis evaluating the association between visitor perception of the quality of the recreational benefits of nature-based tourism in Karamjal, Sundarban and various independent variables. $\mathrm{R}^{2}$ value explaining the variation in visitor perception

\begin{tabular}{lll}
\hline Independent variables & $\mathrm{t}$ & $p$ \\
\hline Financial status & 2.930 & 0.004 \\
Age of visitor & -1.919 & 0.057 \\
Type of visitor & 1.416 & 0.159 \\
Occupation & -0.641 & 0.523 \\
Household size & 0.545 & 0.587 \\
Gender & -0.527 & 0.599 \\
Literacy level & -0.324 & 0.746 \\
Constant & 18.595 & 0.0001 \\
$\mathrm{R}^{2}$ & 0.055 & \\
\hline
\end{tabular}

\section{Discussion}

Tourism has become one of the most important sectors in many developing countries, a high proportion of which have beautiful natural resources. For example, in southern and eastern Africa, tourism is a key economic activity (Chiutsi, Mukoroverwa, Karigambe, \& Kumira, 2011; Eagles, 1997). Tanzania and Kenya can, in this respect, be categorized as tourism successful countries. Developed countries such as Australia are, on the other hand, more experienced than most Asian countries in regards to nature-based tourism (Shea \& Sharp, 1993). Increases in economic growth, disposable income, leisure time, and political stability and widespread tourism campaigns, among others factors, have fuelled a significant growth in tourism (Tisdell, 1997). Developing countries have some common characteristics, such as extreme poverty and widespread conflicts, extensive political corruption, poor governance, a lack of political and social stability, weakness of human resources, and economic vulnerability (Dwyer, Forsyth, Madden, \& Spurr, 2000). The tourism sector in Bangladesh is in need of attention. This country has the largest mangrove forest in the world, the Sundarban. A major obstacle to Bangladesh becoming a vibrant international tourist destination is political instability and insecurity (Tisdell, 1997). Efficient security services 
have been identified as pre-conditions for modern tourism (Hai \& Chik, 2011). The feeling of being unsafe in Bangladesh is a substantial barrier that discourages not only foreign but also local tourists (Quader, 2008). It has become obvious that foreign tourists do not prefer to visit areas with political instability (Quader, 2008), and if they travel to areas with unstable conditions, they might prefer to come with a group or with friends rather than bringing family members. Women are the most vulnerable group in a masculine society such as Bangladesh, and they might feel unsafe travelling outside of their homes alone when safety and security are of concern in association with their movements. Under such circumstances, females may be less likely to travel to remote or insecure areas. Thus, among visitors in our study area, the proportion of females was very low compared to males; however, the proportion of female foreign visitors were much higher than the proportion of female local visitors. Guha and Ghosh (2007) also identified similar results, finding that the surrounding population did not have any problems with tourism. Rather, this population was found to believe tourism was a good means of communication and transportation development.

The number of foreign visitors reduced dramatically during January to March 2015 due to political instability in Bangladesh. as reported by the Tour Operators Association of Sundarban. The effect of political instability was also reflected in the rate of visitation by local visitors. As observed in our study, due to political instability, Sundarban entertained the highest number of visitors from different districts of the Khulna division, which is closely located to Sundarban. The visitation rate from other administrative divisions of Bangladesh was negligible, except for the Dhaka division. Some tour operators, for example, "Guide Tours" and "The Bengal Tour," directly organized package trips from Dhaka to Sundarban using their tourist launches. Therefore, a considerable number of local visitors came to Sundarban despite the fact that a political crisis was ongoing throughout the first three months of 2015.

Bangladesh is a developing country in Asia with a high potential for tourism. For a long time, Bangladesh has been an attractive destination for tourists; however, at present, its position is not significant in terms of the international tourism market (Lankford, 1994). However, the potential for increasing international tourism is great. Over the past three decades, numerous studies have been conducted to identify variables significantly influencing visitors' attitudes towards tourism (Brougham \& Butler, 1981; Cavus \& Tanrisevdi, 2002; Lankford, Chen, \& Chen, 1994; Perdue, Long, \& Allen, 1987)). A review of the literature revealed that most attitudinal studies have focused on examining the differences in tourist attitudes according to their socioeconomic and demographic attributes (Wang et al. 2010). Tourism expenditures have been found to be directly linked with family incomes (Abbruzzo, Brida, \& Scuderi, 2014). Similar to our findings, previous studies have also identified household income to have a positive impact on recreational behaviour (Landry, Allen, Cherry, \& Whitehead, 2012). Visitors (mostly foreigners) with high income may be willing to pay more if the recreational quality of a park improves. These tourists may also be more satisfied with Sundarban. Education was identified as another factor significantly contributing to the variation in visitor perception of the improvement of tourism in Sundarban. Less educated visitors have been found to have a poorer perception of nature-based tourism and laws and regulations relating to nature and environmental philosophy within protected areas (Ahmad \& Rahman, 1997).

In conclusion, the government should take responsibility for increasing the budget allocated to improving tourism facilities, with a specific emphasis on attracting more foreigner visitors. Additionally, information regarding the social characteristics of visitors should be incorporated into decision-making and management processes to allow for better development of sustainable nature-based tourism in Sundarban (Redclift, 1999). Finally, a management approach may be successful if park managers and stakeholders are encouraged to establish a dialogue and work together as a team, including the supporting and sharing of decision-making processes (Costanza, 2001; Meppem, 2000; Tress \& Tress, 2003).

\section{References}

Abbruzzo, A., Brida, J. G., \& Scuderi, R. (2014). Determinants of individual tourist expenditure as a network: empirical findings from Uruguay. Tourism Management, 43, 36-45. http://dx.doi.org/10.1016/j.tourman. 2014.01.014

Ahmad, M. R., \& Rahman, M. M. (1997). Visitor's participation in outdoor recreation activities Bhawal National Park with respect to some socio-economic variables. Bangladesh Journal of Forest Science, 26(1), 37-42. Retrieved from http://cabdirect.org/cabdirect/abstract/19990607619

BBS. (2011). Statistical yearbook 2011. Bangladesh Bureau of Statistics, Dhaka.

Biswas, S. R., Choudhury, J. K., Nishat, A., \& Rahman, M. (2007). Do invasive plants threaten the Sundarban mangrove forest of Bangladesh? Journal of Forest Ecology and Management, 245(1), 9. http://dx.doi.org/ 10.1016/j.foreco.2007.02.011 
Brougham, J. E., \& Butler, R. W. (1981). A segmentation analysis of resident attitudes to the social impact of tourism. Annals of Tourism Research, 8, 569-589. http://dx.doi.org/10.1016/0160-7383(81)90042-6

Cavus, S., \& Tanrisevdi, A. (2002). Residents' attitudes toward tourism: a case study of Kusadasi, Turkey. Tourism Analysis, 7(3-4), 259-268. http://dx.doi.org/10.3727/108354203108750102

Chiutsi, S., Mukoroverwa, M., Karigambe, P., \& Kumira, M. (2011). The theory and practice of ecotourism in Southern Africa. Journal of Hospitality Management and Tourism, 2(2), 14-21.

Costanza, R. (2001). Visions, values, valuation, and the need for an ecological economics. Ecological Economics, 51, 459-468. http://dx.doi.org/10.1641/0006-3568(2001)051[0459:VVVATN]2.0.CO;2

Das, B., \& Bandyopadhyay, D. A. (2013). Ecotourism of Sundarban in Gangatic Delta. International Journal of Scientific \& Engineering Research, 4(5), 459-468.

Dwyer, L., Forsyth, P., Madden, J., \& Spurr, R. (2000). Economic impacts of inbound tourism under different assumptions about the macro economy. Current Issues in Tourism, 3(4), 325-363. http://dx.doi.org/10.1080/ 13683500008667877

Eagles, P. F. J. (1997). International ecotourism management: Using Australia and Africa as case studies. Retrieved from http://www.ahs.uwaterloo.ca/rec/ecotour.htm

Folke, C., Carpenter, S., Elmqvist, T., Gunderson, L., Holling, C. S., \& Walker, B. (2002). Resilience and sustainable development: Building adaptive capacity in a world of transformations. Ambio, 31(5), 437-440. http://dx.doi.org/10.1639/0044-7447(2002)031[0437:Rasdba]2.0.Co;2

Guha, I., \& Ghosh, S. (2007). Does tourism contribute to local livelihoods? A case study of tourism, poverty and conservation in the Indian Sundarbans. Retrieved from Kathmandu, Nepal.

Hai, M. A., \& Chik, A. R. (2011). Political stability: Country image for tourism industry in Bangladesh. Paper presented at the Proceeding of the International Conference on Social Science, Economics and Art 2011, Hotel Equatorial Bangi-Putrajaya, Malaysia.

Haque, A. K. E., \& Aich, D. (2014). Economic valuation of ecosystem services in Bangladesh Sundarban Delta Vision 2050 - a first step in its formulation. Retrieved from Bangladesh Country Office, Dhaka.

Hasan, A. (2012). 'Package eco-tour' as special interest tourism product-Bangladesh perspective. Developing Country Studies, 2(1), 1-9.

Honey, M. (2008). Ecotourism and sustainable development: Who owns paradise? (2nd ed.). Washington DC, USA: Island Press.

Iqball, M. S., Parvin, M., Salekuzzaman, M., Haque, S. E., Islam, M. R., \& Ahmed, M. S. (2010). Ecotourism in Sundarbans and its surrounding- A possible sustainable option for alternative livelihood development. Bangladesh Research Publications Journal, 4(3), 244-253. http://dx.doi.org/10.5772/55749

IUCN. (2015, 27.10.2014). IUCN Red List of Threatened Species. IUCN Red List. Retrieved from http://discover.iucnredlist.org/species/41766

Landry, C. E., Allen, T., Cherry, T., \& Whitehead, J. C. (2012). Wind turbines and coastal recreation demand. Resource and Energy Economics, 34(1), 93-111. http://dx.doi.org/10.1016/j.reseneeco.2011.10.001

Lankford, V. (1994). Attitudes and perceptions toward tourism and rural regional development. Journal of Travel Research, 32(2), 35-43. http://dx.doi.org/10.1177/004728759403200306

Lankford, V., Chen, Y., \& Chen, W. (1994). Tourism's impacts in the Penghu National Scenic Area, Taiwan. Tourism Management, 15(3), 222-227. http://dx.doi.org/10.1016/0261-5177(94)90109-0

Mallya, A. (2006). Wildlife tourism and conservation. Dehli, India: Gnosis, Publisher.

Meppem, T. (2000). The discursive community: evolving institutional structures for planning sustainability. Ecological Economics, 34(1), 47-61. http://dx.doi.org/10.1016/S0921-8009(00)00151-8

Perdue, R. R., Long, P. T., \& Allen, L. (1987). Rural resident tourism perceptions and attitudes. Annals of Tourism Research, 14(3), 420-429. http://dx.doi.org/10.1016/0160-7383(87)90112-5

Quader, S. B. (2008). A land with potential for tourism. Retrieved from http://www.thedailystar.net/ story.php?nid=21277

Redclift, M. (1999). Sustainability and sociology: Northern preoccupations. London: Zed Books Ltd. 
Shea, S., \& Sharp, J. (1993). Western Australia's natural advantage - Capitalising on the nature-based tourism potential of the north. Exmouth, Western Australia: Northern Australia Development Council Conference.

Siddiqi, N. A. (2001). Mangroves of Bangladesh Sundarbans and Accretion Areas. In L. D. d. Lacerda (Ed.), Mangrove ecosystem: Function and management (pp. 142-157). Berlin, Heidelberg, New York: Springer.

Tisdell, C. (1997). Tourism development in India and Bangladesh: General issues, illustrated by ecotourism in the Sunderbans. Tourism Recreation Research, 22(1), 26-33. http://dx.doi.org/10.1080/02508281.1997.11 014783

Tress, B., \& Tress, G. (2003). Scenario visualisation for participatory landscape planning - a study from Denmark. Landscape and Urban Planning, 64(3), 161-178. http://dx.doi.org/10.1016/S0169-2046(02) 00219-0

Walker, B., Carpenter, S., Anderies, J., Abel, N., Cumming, G. S., Janssen, M., Lebel, L., Norberg, J., Peterson, G. D., \& Pritchard, R. (2002). Resilience management in social-ecological systems: a working hypothesis for a participatory approach. Conservation Ecology, 6(1). http://dx.doi.org/WOS:000177892600018

Wightm, P. A. (1996). North American ecotourism markets: motivations, preferences and destinations. Journal of Travel Research, 34(2), 3-10. http://dx.doi.org/10.1177/004728759603500102

WTO. (2000). WTO news (2nd quarter 2000 Issue 2). Retrieved from Madrid, Spain.

\section{Copyrights}

Copyright for this article is retained by the author(s), with first publication rights granted to the journal.

This is an open-access article distributed under the terms and conditions of the Creative Commons Attribution license (http://creativecommons.org/licenses/by/4.0/). 